\title{
First-trimester Combined Screening Test for Aneuploidies in Brazilian Unselected Pregnancies: Diagnostic Performance of Fetal Medicine Foundation Algorithm
}

\section{Rastreio combinado do primeiro trimestre para aneuploidias em gestantes brasileiras não selecionadas: desempenho diagnóstico do algoritmo da Fetal Medicine Foundation}

\author{
Laila Pinheiro Abi Abib ${ }^{1}$ Renato Augusto Moreira de Sá ${ }^{1} \quad$ Fernando Maia Peixoto-Filho ${ }^{1}$ \\ 1 Department of Woman and Child Health, Universidade Federal \\ Fluminense, Niterói, RJ, Brazil \\ Rev Bras Ginecol Obstet 2018;40:384-389. \\ Address for correspondence Renato Augusto Moreira de Sá, PhD, \\ Departamento Materno-Infantil, Universidade Federal Fluminense, \\ Avenida Marques de Paraná, 303 - $2^{\circ}$ andar. Centro - Niterói \\ 24033-900, Brazil (e-mail: rsa@cpdt.com.br).
}

\begin{abstract}
Keywords

- chromosomal anomalies

- aneuploidy

- trisomy 21

- nuchal translucency measurement

- PAPP-A

- $\beta$-HCG

- pregnancy complications

- biomarkers

- screen tests on maternal serum
\end{abstract}

Objective The main objective of this study was to examine the diagnostic performance of the first-trimester combined test for aneuploidies in unselected pregnancies from Rio de Janeiro and compare it with the examples available in the literature. Methods We investigated 3,639 patients submitted to aneuploidy screening from February 2009 to September 2015. The examination is composed of the Fetal Medicine Foundation risk evaluation based on nuchal translucency evaluation, mother's age, presence of risk factors, presence of the nasal bone and Doppler of the ductus venous in addition to biochemical analysis of pregnancy-associated plasma protein A (PAPP-A) and beta-human chorionic gonadotropin ( $\beta-\mathrm{hCG}$ ) markers. The cut-off point for high risk for aneuploidies was defined as greater than 1:100, with intermediate risk defined between 1:100 and 1:1,000, and low risk defined as less than 1:1,000. The variable aneuploidy was considered as a result not only of trisomy of chromosome 21 but also trisomy of chromosomes 13 and 18.

Results Excluding the losses, the results of 2,748 patients were analyzed. The firsttrimester combined test achieved $71.4 \%$ sensitivity with a $7.4 \%$ false-positive (FP) rate, specificity of $92.6 \%$, positive predictive value (PPV) of $6.91 \%$ and negative predictive value (NPV) of $99.76 \%$, when the cut-off point considered was greater than 1:1,000. Through a receiving operating characteristics (ROC) curve, the cut-off point that maximized the sensitivity and specificity for the diagnosis of aneuploidies was defined as $1: 1,860$. When we adjusted the false-positive (FP) rate to $5 \%$, the detection rate for this analysis is $72.7 \%$, with a cut-off point of $1: 610$.

Conclusion The combined test of aneuploidy screening showed a detection rate inferior to those described in the literature for a higher FP rate. received

October 3, 2017

accepted

May 17, 2018

published online

July 16,2018
DOI https://doi.org/

10.1055/s-0038-1666996.

ISSN 0100-7203.
Copyright (e 2018 by Thieme Revinter

Publicações Ltda, Rio de Janeiro, Brazil
License terms

(c) $(1) \$$ 


\section{Resumo}

Palavras-chave
- anomalias
cromossômicas
- aneuploidia
- trissomia 21
- medida da
translucência nucal
- PAPP-A
- $\beta$-HCG
- complicações de
gravidez
- biomarcadores
- testes de rastreio em
soro materno

Objetivo O objetivo principal deste estudo foi examinar o desempenho diagnóstico do rastreio combinado de aneuploidias do primeiro trimestre em gestações não selecionadas do Rio de Janeiro e compará-lo com os exemplos disponíveis na literatura. Métodos Investigamos 3.639 pacientes submetidas à triagem para aneuploidia, de fevereiro de 2009 a setembro de 2015 . O exame é composto pela avaliação do risco da Fetal Medicine Foundation com base na avaliação da translucência nucal, idade da mãe, presença de fatores de risco, presença de osso nasal e Doppler do ducto venoso, além da análise bioquímica dos marcadores proteína $A$ plasmática associada à gravidez (PAPP-A) e gonadotrofina coriônica humana-beta ( $\beta-\mathrm{hCG}$ ). O ponto de corte para alto risco de aneuploidias foi definido como superior a 1:100, para risco intermediário foi definido entre 1: 100 e 1:1.000 e para baixo risco foi definido como inferior a 1:1.000. A variável aneuploidia foi considerada não apenas como resultado da trissomia do cromossomo 21, mas também da trissomia dos cromossomos 13 e 18.

Resultados Excluindo as perdas, foram analisados os resultados de 2.748 pacientes. $O$ teste combinado do primeiro trimestre alcançou $71,4 \%$ de sensibilidade com uma taxa de falsos positivos (FPs) de 7,4\%, especificidade de $92,6 \%$, (valor preditivo positivo) VPP de $6,91 \%$ e (valor preditivo negativo) VPN de $99,76 \%$, quando o ponto de corte considerado foi maior que 1:1.000. Através de uma curva de característica de operação do receptor (COR), o ponto de corte que maximizou a sensibilidade e especificidade para o diagnóstico de aneuploidias foi de 1:1.860. Quando corrigimos a taxa de FP para $5 \%$, a taxa de detecção para esta análise é de 72,7\%, com um ponto de corte de 1:610. Conclusão $\mathrm{O}$ rastreio combinado de aneuploidia mostrou uma taxa de detecção inferior à descrita na literatura para uma maior taxa de FP.

\section{Introduction}

Chromosomal diseases are the leading cause of perinatal mortality and developmental abnormalities. ${ }^{1}$ In 1866, Langdon Down described for the first time the syndrome that today bears his name, in reference to individuals affected by the trisomy of chromosome 21 , the most common chromosomal aneuploidy in humans $(0.12 \%$ or 1 in 800 births $){ }^{1}$ The diagnosis of aneuploidies depends on invasive procedures that are associated with risks of gestational loss. The total fetal loss for chorionic villus sampling and amniocentesis ranges from 1.5 to $2.0 \%{ }^{2}$ In an attempt to indicate these tests only to patients considered to be at high risk, several screening strategies have been developed. Therefore, prenatal genetic counseling is necessary. In addition, several gynecology and obstetrics societies around the world recommend prenatal screening for aneuploidies in all pregnant women. ${ }^{3}$

First-trimester screening allows early diagnosis of aneuploidy. There are many strategies that are available for chromosomal abnormality screening. The first-trimester combined test was introduced by Wald and Hackshaw $(1997)^{4}$ and is one of the most popular and useful strategies. In this screening strategy, the risk is calculated based on the sonographic findings and maternal serum levels of free betahuman chorionic gonadotrophin ( $\beta$-hCG) and pregnancyassociated plasma protein A (PAPP-A). ${ }^{4}$ The screening performance of the combined test has been reported to range from 82 to $95 \%$ detection rate, with a 5 to $7 \%$ false positive (FP) rate. ${ }^{5-15}$ However, it may vary between different ethnicities as well as by age group. ${ }^{16-18}$

According to the Fetal Medicine Foundation (FMF) proposed screening, patients with a risk lower than 1:1,000 are classified as low risk and are reassured. If we include the additional ultrasound marker of the presence of nasal bone and Doppler of the venous duct, the cut-off point for highrisk patients will be $1: 100$. Patients with risk between $1: 100$ and 1:1,000 are considered to have an intermediate risk. ${ }^{19}$

In Brazil, the first-trimester combined test has been widely used but little information is available on the performance of this screening method in the Brazilian population. The aim of this study was to examine the performance of the first-trimester combined test in unselected pregnancies from Rio de Janeiro by analyzing the detection rates (sensitivity), specificity, positive and negative predictive values, percentage of FPs and relative risks for the occurrence of aneuploidy, as well as to estimate the sensitivity and specificity for various risk cut-off points to construct a receiving operator characteristics (ROC) curve.

\section{Methods}

The current study was based on a cohort of singleton gestation women who booked a combined test for first-trimester risk assessment at our center from February 2009 to September 2015. Women with pregnancies resulting from ovum donation, 
multiple gestation or without postpartum follow-up were excluded.

The fetal crown rump length (CRL) was measured, and if it was between 45 and $84 \mathrm{~mm}$, we evaluated the following fetal ultrasound parameters: nuchal translucency (NT), nasal bone (NB), and ductus venosus (DV) flow. After that, the PAPP-A and free $\beta$-hCG levels in the maternal serum were determined. The sample was analyzed by means of a fluoroimmunometric assay using an automated AutoDelfia system (Perkin Elmer, Wallac, Turku, Finland). Analysis of NT thickness, PAPPA-A and free $\beta$-hCG was performed using the algorithm provided by the FMF, in London, UK, and was calculated using the Astraia software (astraia software gmbh, Munich, Germany).

The ultrasound parameters were evaluated only by experienced sonographers who had been certificated by the FMF for 11-13 weeks' scan. The measurements were taken using a transabdominal transducer ( $5 \mathrm{MHz}$ curvilinear transducer, Voluson E6 [GE Healthcare, Milwaukee, WI, USA]).

First-trimester risk assessment was provided for trisomy 21, trisomy 18 and trisomy 13 . The risk was calculated using a previously described algorithm. ${ }^{20}$ The cut-off point for high risk for aneuploidies was defined as greater than 1:100, intermediate risk was defined to be between 1:100 and 1:1,000 and low risk was defined as less than $1: 1,000 .{ }^{4}$ The variable aneuploidy was considered as a result not only of trisomy of chromosome 21 but also the trisomy of chromosomes 13 and 18. Patients classified as high or intermediate risk were referred for fetal medicine counseling. Chorionic villus sampling or amniocentesis was performed for karyotype analysis in women who expressed their wish and signed an informed consent.

Information about patient characteristics, chromosomal abnormalities and the pregnancy outcome was obtained by the personnel, hospital registry or the postpartum routine follow-up registry.

The statistical analysis was performed using the SPSS software version 20.0 (IBM Corp., Armonk, NY, USA). A descriptive analysis of the population was performed in the form of mean and median with standard deviation (SD) for quantitative variables and the proportions, percentages and ratios by calculating the $95 \%$ confidence intervals (95\%CIs) for categorical variables.

We calculated detection rates (sensitivity), specificity, positive and negative predictive values and percentage of FP for aneuploidies. $P$-values $<0.05$ were considered statistically significant. For quantitative variables, the Mann-Whitney test was used for comparison between two independent groups, and for categorical variables, we used the Chi-square test. A ROC curve was constructed to estimate the sensitivity and specificity of aneuploidy screening for various risk cut-off points. The Spearman coefficient was calculated to evaluate the correlation of four factors (age, NT, $\beta$-hCG and PAPP-A) with the risk for aneuploidies in the first trimester.

\section{Results}

Among 3,639 pregnant women who underwent a combined test in the first-trimester risk assessment at the perinatal group, a total of 2,748 hospital registries were analyzed.
Among the patients that were excluded, there were 775 that were lost to follow-up after delivery or the pregnancy resulted from ovum donation, and 116 cases of multiple gestation. The ethnic origin of the pregnant women was almost all Latin American.

The median CRL was $62.5 \mathrm{~mm}$ (with a range from 45.0 to $84.0 \mathrm{~mm}$ ). The median maternal age was 33 years (with a range from 18 to 46 years). A total of 1,142 (41.6\%) of the women were aged 35 years or older, and 1,606 $(58,45 \%)$ women were aged between 18 and 34 years old. A total of 173 (6.3\%) of the women were aged 41 years or older.

Considering the cut-off point for high risk for aneuploidies (risk greater than 1:100), 62 (2.3\%) women were classified as high risk, 155 (5.6\%) as intermediate risk (between $1: 100$ and $1: 1,000)$, and 2.531 (92.1\%) as low risk (less than 1:1,000). In the population that was screened, there were 21 pregnancies $(0.76 \%)$ detected for aneuploidy.

The Spearman coefficient was calculated in our population for four algorithm composition factors, age, TN, $\beta$-hCG and PAPP-A, to analyze the influence of these factors in the risk assessment. Among the factors that influence the risk for aneuploidies, age is the one with the greatest weight (-Table 1). Also, if we analyze these four variables separately, we can see that all of them influence the risk classification with a statistically significant $p$-value (-Table 2 ). In the groups aged under 34 years, between 35 and 40 years and over 41 years, 71 (4.4\%), 77 (7.9\%) and 69 (39.9\%) patients, respectively, were classified as intermediate and high risk and were referred for fetal medicine counseling (-Table 3 ). When stratifying by age group, we found that the chance of being classified as high/medium risk is 1.8 times higher in the age group between 35 and 40 years and up to 9 times higher in the age group over 41 years, in relation to the age group up to 34 years ( $\mathbf{- T a b l e ~} \mathbf{3}$ ).

In the present report, the detection rate for aneuploidy or sensitivity was $42.9 \%$, specificity was $98.1 \%$, for a FP rate of $1.9 \%$, positive predictive value (PPV) of $14.52 \%$ and negative predictive value (NPV) of $99.55 \%$ for a $1: 100$ cut-off point. The first-trimester combined test achieved $71.4 \%$ sensitivity with a $7.4 \%$ FP rate, specificity of $92.6 \%$, PPV of $6.91 \%$ and NPV of $99.76 \%$, when the cut-off point was adjusted to greater than $1: 1,000$ ( - Table 4 ).

Table 1 Influence of algorithm composition factors in the studied population's first-trimester risk assessment

\begin{tabular}{|l|l|l|}
\hline Algorithm Factor & \multicolumn{2}{|l|}{$\begin{array}{l}\text { Risk for aneuploidies } \\
\text { correlation }\end{array}$} \\
\cline { 2 - 3 } & Spearman & $p$ \\
\hline Maternal Age & -0.770 & $<0.001$ \\
\hline NT & -0.111 & $<0.001$ \\
\hline Free $\beta$-HCG & -0.122 & $<0.001$ \\
\hline PAPP-A & 0.163 & $<0.001$ \\
\hline
\end{tabular}

Abbreviations: $\beta$-HCG, beta-human chorionic gonadotropin; NT, nuchal translucency; PAPP-A, pregnancy-associated plasma protein A. 
Table 2 Correlation between four variables (age, nuchal translucency, $\beta$-hCG and PAPP-A) and the risk classification of aneuploidy

\begin{tabular}{|c|c|c|c|c|c|c|c|}
\hline Variables and risk for aneuploidy & $\mathrm{n}$ & Average & SD & Minimum & Median & Maximum & $P$-value* \\
\hline \multicolumn{8}{|l|}{ Age (years) } \\
\hline High/intermediate risk & 217 & 37.1 & 5.5 & 22.0 & 38.0 & 50.0 & \multirow[t]{2}{*}{$<0.001$} \\
\hline Low risk & 2,531 & 33.3 & 4.2 & 18.0 & 33.0 & 49.0 & \\
\hline \multicolumn{8}{|l|}{ Nuchal translucency (mm) } \\
\hline High/intermediate risk & 217 & 2.04 & 1.13 & 0.70 & 1.80 & 7.20 & \multirow[t]{2}{*}{$<0.001$} \\
\hline Low risk & 2,531 & 1.50 & 0.47 & 0.50 & 1.50 & 9.00 & \\
\hline \multicolumn{8}{|l|}{$\beta$-hCG (MoM) } \\
\hline High/intermediate risk & 216 & 1.71 & 1.40 & 0.09 & 1.25 & 8.34 & \multirow[t]{2}{*}{$<0.001$} \\
\hline Low risk & 2,529 & 2.06 & 24.42 & 0.01 & 1.01 & 933.00 & \\
\hline \multicolumn{8}{|l|}{ PAPP-A (MoM) } \\
\hline High/intermediate risk & 215 & 0.915 & 0.702 & 0.029 & 0.680 & 3.964 & \multirow[t]{2}{*}{$<0.001$} \\
\hline Low risk & 2,499 & 1.437 & 0.960 & 0.108 & 1.228 & 9.987 & \\
\hline
\end{tabular}

Abbreviations: $\beta$-hCG, beta-human chorionic gonadotropin; MoM, Multiple of the Median; PAPP-A, pregnancy-associated plasma protein A; SD, standard deviation.

Table 3 Combined test risk classification for aneuploidies in the first trimester by maternal age group $(n=2,748)$

\begin{tabular}{|l|l|l|l|l|}
\hline Patient Age & $\begin{array}{l}\text { Low risk for } \\
\text { aneuploidies } \\
\mathbf{n}(\%)\end{array}$ & $\begin{array}{l}\text { Intermediate and high } \\
\text { risk for aneuploidies } \\
\mathbf{n}(\%)\end{array}$ & $\begin{array}{l}\text { Total } \\
\mathbf{n}(\%)\end{array}$ & $\begin{array}{l}\text { Intermediate } \\
\text { and high risk } \\
\text { PR (CI95\%) }\end{array}$ \\
\hline$\leq 34$ years & $1,535(95.6)$ & $71(4.4)$ & $1,606(100)$ & 1 \\
\hline $35-40$ years & $892(92.1)$ & $77(7.9)$ & $969(100)$ & $1.8(1.3-2.5)$ \\
\hline$\geq 41$ years & $104(60.1)$ & $69(39.9)$ & $173(100)$ & $9.0(6.7-12.1)$ \\
\hline Total & $2,531(92.1)$ & $217(7.9)$ & $2,748(100)$ & \\
\hline
\end{tabular}

Abbreviations: $\mathrm{Cl}$, confidence interval; PR, prevalence ratio.

Table 4 Detection rate or sensitivity, specificity, positive and negative predictive values for aneuploidy at different cut-off points

\begin{tabular}{|c|c|c|c|c|c|c|c|c|c|}
\hline \multicolumn{2}{|c|}{ Risk cut-off } & \multicolumn{4}{|c|}{ Occurrence of aneuploidy } & \multicolumn{2}{|l|}{ Total } & \multicolumn{2}{|c|}{ Predictive values } \\
\hline & & \multicolumn{2}{|l|}{ Yes } & \multicolumn{2}{|l|}{ No } & & & \multirow{2}{*}{ Positive } & \multirow{2}{*}{ Negative } \\
\hline & & $\mathrm{n}$ & $(\%)$ & $\mathbf{n}$ & $(\%)$ & $\mathrm{n}$ & $(\%)$ & & \\
\hline \multirow[t]{2}{*}{$1 / 100$} & Positive $(>1 / 100)$ & 9 & $(42.9)$ & 53 & $(1.9)$ & 62 & $(2.3)$ & \multirow[t]{2}{*}{$14.52 \%$} & \multirow[t]{2}{*}{$99.55 \%$} \\
\hline & Negative $(<1 / 100)$ & 12 & $(57.1)$ & 2,674 & (98.1) & 2,686 & (97.7) & & \\
\hline \multirow[t]{2}{*}{$1 / 1,000$} & Positive $(>1 / 1,000)$ & 15 & (71.4) & 202 & $(7.4)$ & 217 & $(7.9)$ & \multirow[t]{2}{*}{$6.91 \%$} & \multirow[t]{2}{*}{$99.76 \%$} \\
\hline & Negative $(<1 / 1,000)$ & 6 & $(28.6)$ & 2,525 & $(92.6)$ & 2,531 & $(92.1)$ & & \\
\hline \multirow[t]{2}{*}{$1 / 1,860$} & Positive $(>1 / 1,860)$ & 17 & $(81.0)$ & 390 & $(14.3)$ & 407 & $(14.8)$ & \multirow[t]{2}{*}{$4.18 \%$} & \multirow[t]{2}{*}{$99.83 \%$} \\
\hline & Negative $(<1 / 1,860)$ & 4 & $(19.0)$ & 2,337 & $(85,7)$ & 2,341 & $(85.2)$ & & \\
\hline
\end{tabular}

When we plotted the ROC curve for our population, the cut-off point that maximized the sensitivity and specificity for the diagnosis of aneuploidies was 1:1,860. If we adjust the FP rate to $5 \%$, the detection rate for this analysis is $72.7 \%$ with a cut-off point of 1:610 (- Table 5).

\section{Discussion}

Many authors have reported that a combined screening test for aneuploidy makes sense because it results in a sensibility of
$80 \%$ and higher. ${ }^{12,21-26}$ However, many critics of the methodology used by these authors cast doubt on these results. ${ }^{14,27,28}$ Therefore, it is important to analyze the combined screening test performance in our own population.

In our study, the FP rate for the first-trimester combined test for chromosomal abnormalities altogether, considering the cutoff of $1: 1,000$, was $7.4 \%$, which was similar to the range of 5 to $7 \%$ found in other studies. It was somewhat higher than the usual set value of $5 \%$. The detection rate was $71.4 \%$, which is less than the values of 75.9 to $95 \%$ produced by other studies. ${ }^{6-8,14,28}$ 
Table 5 Cutoff point defined by plotted ROC curve to detect aneuploidy: sensibility, specificity and predictive values

\begin{tabular}{|l|l|l|l|l|l|}
\hline Criteria defined by plotted ROC curve & Value & Sensibility & Specificity & PPV & NPV \\
\hline Cut-off point to maximize sensitivity and specificity & $1 / 1,860$ & $90.91 \%$ & $85.5 \%$ & $2.46 \%$ & $99.96 \%$ \\
\hline Fixed FP ratio at $0.5 \%$ & $1 / 610$ & $72.7 \%$ & $95.0 \%$ & $5.5 \%$ & $99.88 \%$ \\
\hline
\end{tabular}

Abbreviations: FP, false positive; NPV, negative predictive value; PPV, positive predictive value; ROC, receiving operating characteristic.

The detection rate was much lower (42.9\%) if we consider the cut-off to be $1: 100$, for a FP rate of $1.9 \%$. The best result that maximized the sensitivity and specificity for the diagnosis of aneuploidies in our population was 1:1,860. Most likely, our results were influenced by maternal age, because $41.6 \%$ of the women were aged 35 years or older. The influence of maternal age on combined screening test performance was also described in the Chinese population. Pan et $\mathrm{al}^{17}$ demonstrated that the FP rate increases with increasing maternal age.

The limitation of this study is a small sample size in comparison with larger studies. Additionally, because this study was conducted in only one center, the results cannot fully represent the screening performance in all of the Brazilian population. In addition, the overall screening performance might be affected by the test timing. In this study, the first-trimester combined test was performed between $11+0$ and $13+6$ weeks of gestation. Both serum markers and NT are affected by the gestational age of the fetus. The discrimination of PAPP-A is greatest at 10 weeks and declines afterwards, whereas screening performance of free $\beta$-hCG improves with increasing gestational age until 13 weeks. Additionally, there might be a difference in screening power depending on the gestational age of serum marker measurements. The NT was measured by multiple observers; therefore, there is a possibility of error as a result of inter-observer variation. Finally, there were 775 women who were lost to follow-up at the center. There is a possibility that an error has occurred with these women who had no records on aneuploidy screening.

\section{Conclusion}

In conclusion, the combined test of aneuploidies screening showed a detection rate inferior to those described in the literature for a higher FP rate. It may suggest that we have to consider a different cut-off point $(1: 610)$ as a reference for the population assisted at our maternity center to achieve similar performance to the literature.

\section{Contributions}

Abib L. P. A., Sá R. A. M. and Peixoto-Filho F. M. contributed with project and interpretation of data, writing of the article, critical review of the intellectual content and final approval of the version to be published.

\section{Conflicts of Interest}

The authors declare that there are no potential conflicts of interest.

\section{References}

1 Fonseca EB, Cruz J, Sá RA, Di Renzo GC, Nicolaides K. Rastreamento de aneuploidias no primeiro trimestre de gestação: evolução da idade materna à avaliação do DNA fetal livre no sangue. Femina 2014;42:87-93

2 Niederstrasser SL, Hammer K, Möllers M, et al. Fetal loss following invasive prenatal testing: a comparison of transabdominal chorionic villus sampling, transcervical chorionic villus sampling and amniocentesis. J Perinat Med 2017;45(02):193-198. Doi: 10.1515/ jpm-2015-0434

3 Committee on Practice Bulletins-Obstetrics, Committee on Genetics, and the Society for Maternal-Fetal Medicine. Practice Bulletin No. 163: screening for fetal aneuploidy. Obstet Gynecol 2016;127 (05):e123-e137. Doi: 10.1097/AOG.0000000000001406

4 Wald NJ, Hackshaw AK. Combining ultrasound and biochemistry in first-trimester screening for Down's syndrome. Prenat Diagn 1997;17(09):821-829. Doi: 10.1002/(SICI)1097-0223(199709) 17:9<821:AID-PD154>3.0.CO;2-5

5 Spencer K, Spencer CE, Power M, Moakes A, Nicolaides KH. One stop clinic for assessment of risk for fetal anomalies: a report of the first year of prospective screening for chromosomal anomalies in the first trimester. BJOG 2000;107(10):1271-1275. Doi: 10.1111/j.1471-0528.2000.tb11619.x

6 Spencer K, Spencer CE, Power M, Dawson C, Nicolaides KH. Screening for chromosomal abnormalities in the first trimester using ultrasound and maternal serum biochemistry in a one-stop clinic: a review of three years prospective experience. BJOG 2003; 110(03):281-286. Doi: 10.1046/j.1471-0528.2003.02246.x

7 Nicolaides KH, Spencer K, Avgidou K, Faiola S, Falcon O. Multicenter study of first-trimester screening for trisomy 21 in 75821 pregnancies: results and estimation of the potential impact of individual risk-orientated two-stage first-trimester screening. Ultrasound Obstet Gynecol 2005;25(03):221-226. Doi: 10.1002/uog.1860

8 Wald NJ, Rodeck C, Hackshaw AK, Rudnicka A. SURUSS in perspective. Semin Perinatol 2005;29(04):225-235. Doi: 10.1053/j. semperi.2005.05.006

9 Kagan KO, Wright D, Baker A, Sahota D, Nicolaides KH. Screening for trisomy 21 by maternal age, fetal nuchal translucency thickness, free beta-human chorionic gonadotropin and pregnancyassociated plasma protein-A. Ultrasound Obstet Gynecol 2008;31 (06):618-624. Doi: 10.1002/uog.5331

10 Wald NJ, Rodeck C, Hackshaw AK, Walters J, Chitty L, Mackinson AM; SURUSS Research Group. First and second trimester antenatal screening for Down's syndrome: the results of the Serum, Urine and Ultrasound Screening Study (SURUSS). Health Technol Assess 2003;7(11):1-77. Doi: 10.3310/hta7110

11 Engels MA, Heijboer AC, Blankenstein MA, van Vugt JM. Performance of first-trimester combined test for Down syndrome in different maternal age groups: reason for adjustments in screening policy? Prenat Diagn 2011;31(13):1241-1245. Doi: 10.1002/ pd.2873

12 De Biasio P, Siccardi M, Volpe G, Famularo L, Santi F, Canini S. Firsttrimester screening for Down syndrome using nuchal translucency measurement with free beta-hCG and PAPP-A between 10 and 13 weeks of pregnancy-the combined test. Prenat Diagn 1999;19(04):360-363. Doi: 10.1002/(SICI)1097-0223(199904) 19:4<360:AID-PD556>3.0.CO;2-U 
13 Crossley JA, Aitken DA, Cameron AD, McBride E, Connor JM. Combined ultrasound and biochemical screening for Down's syndrome in the first trimester: a Scottish multicentre study. BJOG 2002;109(06):667-676. Doi: 10.1016/S1470-0328(02)01394-0

14 Lee FK, Chen LC, Cheong ML, Chou CY, Tsai MS. First trimester combined test for Down syndrome screening in unselected pregnancies - a report of a 13-year experience. Taiwan J Obstet Gynecol 2013;52(04):523-526. Doi: 10.1016/j.tjog.2013.10.012

15 Manotaya S, Zitzler J, Li X, et al. Effect of ethnicity on first trimester biomarkers for combined trisomy 21 screening: results from a multicenter study in six Asian countries. Prenat Diagn 2015;35(08):735-740. Doi: 10.1002/pd.4602

16 Li SW, Barrett AN, Gole L, et al. The assessment of combined first trimester screening in women of advanced maternal age in an Asian cohort. Singapore Med J 2015;56(01):47-52. Doi: 10.11622/smedj.2015009

17 Pan M, Han J, Yang X, Zhen L, Liao C, Li DZA. A 1st-trimester combined screening test in pregnant women of advanced maternal age in a Chinese population. J Obstet Gynaecol 2015;35(02): 121-124. Doi: 10.3109/01443615.2014.940297

18 Park SY, Jang IA, Lee MA, Kim YJ, Chun SH, Park MH. Screening for chromosomal abnormalities using combined test in the first trimester of pregnancy. Obstet Gynecol Sci 2016;59(05): 357-366. Doi: 10.5468/ogs.2016.59.5.357

19 Nicolaides KH. Screening for fetal aneuploidies at 11 to 13 weeks. Prenat Diagn 2011;31(01):7-15. Doi: 10.1002/pd.2637

20 Spencer K, Nicolaides KH. A first trimester trisomy 13/trisomy 18 risk algorithm combining fetal nuchal translucency thickness, maternal serum free beta-hCG and PAPP-A. Prenat Diagn 2002;22 (10):877-879. Doi: 10.1002/pd.420

21 Orlandi F, Damiani G, Hallahan TW, Krantz DA, Macri JN. Firsttrimester screening for fetal aneuploidy: biochemistry and nuchal translucency. Ultrasound Obstet Gynecol 1997;10(06):381-386. Doi: 10.1046/j.1469-0705.1997.10060381.x

22 Biagiotti R, Brizzi L, Periti E, d'Agata A, Vanzi E, Cariati E. First trimester screening for Down's syndrome using maternal serum PAPP-A and free beta-hCG in combination with fetal nuchal translucency thickness. Br J Obstet Gynaecol 1998;105(08): 917-920. Doi: 10.1111/j.1471-0528.1998.tb10239.x

23 Cuckle HS, van Lith JM. Appropriate biochemical parameters in firsttrimester screening for Down syndrome. Prenat Diagn 1999;19 (06):505-512. Doi: 10.1002/(SICI)1097-0223(199906)19:6<505: AID-PD572>3.0.CO;2-6

24 de Graaf IM, Pajkrt E, Bilardo CM, Leschot NJ, Cuckle HS, van Lith JM. Early pregnancy screening for fetal aneuploidy with serum markers and nuchal translucency. Prenat Diagn 1999;19(05): 458-462. Doi: 10.1002/(SICI)1097-0223(199905)19:5<458: AID-PD569>3.0.CO;2-A

25 Spencer K, Souter V, Tul N, Snijders R, Nicolaides KH. A screening program for trisomy 21 at 10-14 weeks using fetal nuchal translucency, maternal serum free beta-human chorionic gonadotropin and pregnancy-associated plasma protein-A. Ultrasound Obstet Gynecol 1999;13(04):231-237. Doi: 10.1046/j.1469-0705.1999.13040231.x

26 Tsukerman GL, Gusina NB, Cuckle HS. Maternal serum screening for Down syndrome in the first trimester: experience from Belarus. Prenat Diagn 1999;19(06):499-504. Doi: 10.1002/ (SICI)1097-0223(199906)19:6<499:AID-PD555>3.0.CO;2-6

27 Schuchter K, Hafner E, Stangl G, Metzenbauer M, Höfinger D, Philipp K. The first trimester 'combined test' for the detection of Down syndrome pregnancies in 4939 unselected pregnancies. Prenat Diagn 2002;22(03):211-215. Doi: 10.1002/ pd.288

28 Baer RJ, Flessel MC, Jelliffe-Pawlowski LL, et al. Detection rates for aneuploidy by first-trimester and sequential screening. Obstet Gynecol 2015;126(04):753-759. Doi: 10.1097/AOG.0000000000001040 